\title{
Potencial de inibição da regeneração de raízes e plântulas em sementes germinantes de Eugenia pyriformis
}

\author{
Talita Silveira Amador ${ }^{(1)}$ e Claudio José Barbedo(2)
}

\begin{abstract}
(1)Universidade Estadual Paulista, Instituto de Biociências, Programa de Pós-Graduação em Ciências Biológicas, Distrito de Rubião Jr., s/no, CEP 18618-970 Botucatu, SP. E-mail: talitamador@hotmail.com ${ }^{(2)}$ Instituto de Botânica, Núcleo de Pesquisa em Sementes, Avenida Miguel Stéfano, ํo 3.687, CEP 04301-902 São Paulo, SP. E-mail: claudio.barbedo@pesquisador.cnpq.br
\end{abstract}

\begin{abstract}
Resumo - O objetivo deste trabalho foi avaliar o potencial de inibição da formação de raízes e plântulas, em sementes germinantes de uvaieira (Eugenia pyriformis), fragmentadas e fissuradas. As sementes foram separadas por tamanho em dois grupos. Cada grupo foi separado em dois subgrupos, um dos quais foi submetido a teste de germinação. As sementes de cada subgrupo foram submetidas a dois tipos de incisão (total ou parcial) e, em seguida, foram avaliadas quanto à produção de raízes e plântulas. Em sementes com incisão parcial, que apresentavam apenas uma plântula desenvolvida, completou-se a incisão até que as metades fossem separadas. A metade com a raiz foi descartada, e sua complementar foi colocada para germinar, para avaliação da produção de raízes e plântulas nessas frações sem raízes. Em todos os experimentos, utilizou-se o delineamento inteiramente casualizado, em arranjo fatorial 2x2 (tamanho das sementes x germinação visível) e $2 \times 4$ (tamanho das sementes $\mathrm{x}$ tipo de incisão). As sementes fracionadas de uvaieira apresentam potencial para regeneração de raízes e plântulas, e podem produzir mais de uma muda por semente. A germinação inicia processos de inibição da regeneração de novas raízes e plântulas na semente, e a incisão dos cotilédones pode bloquear essa inibição.
\end{abstract}

Termos para indexação: fracionamento, inibidores, produção de mudas, regenerabilidade, uvaieira.

\section{Potential for regeneration inhibition of roots and seedlings in germinating Eugenia pyriformis seeds}

\begin{abstract}
The objective of this work was to evaluate the potential for inhibiting the formation of new roots and seedlings from germinating seeds of "uvaieira" (Eugenia pyriformis), fragmented and fissured. Seeds were separated by size into two groups. Each group was separated into two subgroups, one of which was subjected to germination test. Seeds of each subgroup were subjected to two types of incision (total or partial) and, then, evaluated as for the production of roots and seedlings. Seeds with partial incision, which had only one developed plantlet, had the incision completed until the halves were separated. The half fragment containing the root was discarded, and its complementary part was placed to germinate, in order to evaluate the production of roots and seedlings in these fractions without the roots. The design in all the experiments was completely randomized, in a $2 \times 2$ factorial arrangement (length $\mathrm{x}$ seed visible germination) or $2 \times 4$ (seed size $\mathrm{x}$ incision type). Fragmented seeds of "uvaieira" shows potential for root and seedling regeneration and can produce more than one seedling per seed. Germination starts inhibition processes of formation of new roots and plantlets, and the incision of cotyledons can block this inhibition.
\end{abstract}

Index terms: fragmentation, inhibitors, plantlet production, regenerability, "uvaieira".

\section{Introdução}

A uvaieira Eugenia pyriformis Cambess. (Myrtaceae) é frutífera nativa do Brasil que produz frutos de grande interesse comercial, industrial e farmacológico. Os frutos têm tamanho, forma, cor de casca e sabor atrativos ao consumo in natura, e a composição físico-química de sua polpa oferece grande qualidade organoléptica e nutricional (Scalon et al., 2004a, 2004b; Delgado \& Barbedo, 2007; Oliveira et al., 2010). Diversas espécies de Eugenia apresentam interesse para a exploração industrial. A pitangueira, E. uniflora, por exemplo, tem grande potencial para a produção de fármacos (Pepato et al., 2001) e, na uvaieira, os frutos contêm óleos com propriedades bacteriostáticas, principalmente contra Enterococcus faecalis, bactéria associada à redução do tempo de prateleira de produtos alimentícios (Stieven et al., 2009).

Pesq. agropec. bras., Brasília, v.46, n.8, p.814-821, ago. 2011 
Espécies de Eugenia têm potencial para regenerar novas raízes e até plantas inteiras, a partir de sementes que tiveram parte de sua massa removida, o que raramente ocorre em sementes. Essa característica pode ser usada tecnologicamente para ampliar o potencial de produção de mudas. As características anatômicas do embrião de Eugenia e a origem de novas plântulas a partir desse embrião, quando fracionado, vêm sendo estudadas (Justo et al., 2007; Delgado, 2010). Tem-se verificado que a regeneração de novas raízes e plântulas ocorre somente após o fracionamento da semente (Silva et al., 2003, 2005).

A família Myrtaceae tem algumas espécies com sementes poliembriônicas (Landrum \& Kawasaki, 1997), mas os embriões de Eugenia têm sido descritos como monoembriônicos, que se apresentam como estruturas globosas, em que a diferenciação entre cotilédone e eixo hipocótilo-radícula é visível apenas microscopicamente (Gurgel \& Soubihe Sobrinho, 1951; Salomão \& Allem, 2001; Justo et al., 2007; Delgado et al., 2010). Portanto, o surgimento de raízes e plântulas nessas sementes, após fracionadas, deve decorrer da formação de novos tecidos e não do desenvolvimento de embriões diferenciados já existentes. Contudo, a dependência do fracionamento, para que esses tecidos se desenvolvam, indica que lesões nas sementes podem iniciar algum processo de indução da formação de novas mudas e raízes ou pode bloquear a autoinibição dessas formações em sementes germinantes

Rizzini (1970) verificou que sementes de E. dysenterica DC. têm substâncias inibidoras da germinação, e que esse potencial inibidor aumenta quando o embrião começa a germinar. Desta forma, o estudo de substâncias inibidoras da germinação, em sementes de uvaieira, pode contribuir para elucidar a hipótese da autoinibição, conforme verificado em sementes de cafeeiro (Pereira et al., 2002). Em estudos de organogênese, a taxa de formação e o desenvolvimento de embriões somáticos ou zigóticos são fortemente influenciados pela composição química do meio. O balanço entre açúcares, aminoácidos e reguladores de crescimento, por exemplo, tem mostrado efeitos ora indutores, ora inibidores da formação de novos embriões (Deo et al., 2010; Kanwar et al., 2010; Karami \& Saidi, 2010; Swamy et al., 2010). Assim, em sementes de Eugenia, o início da germinação de um embrião poderia modificar o balanço daqueles compostos, o que torna o meio desfavorável à diferenciação de novas plântulas.

Sementes de Eugenia stipitata ssp. sororia, que também apresentam capacidade de regenerar embriões após fracionamento, tiveram desenvolvimento de plântulas a partir da região da semente oposta à danificada, em que aparentemente estava a zona meristemática (Anjos \& Ferraz, 1999). No entanto, na fração complementar da semente, houve formação de plântulas na superfície do corte, o que indica alguma polaridade na mobilização de hormônios. Tal fato também pode explicar a dependência da separação das metades da semente, para que uma segunda plântula possa ser regenerada. É possível, portanto, que uma vez iniciada a germinação, a semente tivesse produzido substâncias inibitórias à diferenciação de novos tecidos embrionários, pela migração de tais substâncias da região germinante para as demais. Assim, uma fração de semente somente poderia iniciar o desenvolvimento de novas raízes e plântulas, após estar completamente separada dos tecidos restantes.

O objetivo deste trabalho foi verificar o potencial de inibição da formação de raízes e plântulas, em sementes germinantes de uvaieira, pelo fracionamento e fissura das sementes.

\section{Material e Métodos}

Frutos maduros de uvaieira foram coletados na UniversidadeFederaldeLavras, Lavras, MG $\left(21^{\circ} 13^{\prime} 40^{\prime \prime} \mathrm{S}\right.$ e $\left.44^{\circ} 57^{\prime} 50^{\prime \prime} \mathrm{W}\right)$ e levados ao Laboratório do Núcleo de Pesquisa de Sementes, do Instituto de Botânica, São Paulo, SP $\left(23^{\circ} 38^{\prime} \mathrm{S}\right.$ e $\left.46^{\circ} 37^{\prime} \mathrm{W}\right)$. As sementes foram extraídas manualmente, em peneiras com água corrente, tendo-se retirado os resíduos de polpa dos frutos por decantação. Após a lavagem, as sementes permaneceram em repouso sobre papel de germinação, para remoção da água superficial residual, por período não superior a 1 hora. Em seguida, foram classificadas por tamanho, segundo seu maior e menor diâmetro, em pequenas $(17,8 \pm 1,2 \times 14,3 \pm 2,1 \mathrm{~mm} \mathrm{e} \pm 2,1 \mathrm{~g})$ e grandes $(22,0 \pm 2,3 \times 17,6 \pm 1,7 \mathrm{~mm}$ e $\pm 2,9 \mathrm{~g})$, avaliadas quanto ao conteúdo de água e de massa de matéria seca, e submetidas a um teste de germinação. O conteúdo de água (expresso em percentagem, com base na massa de matéria úmida) e o de massa de matéria seca das sementes (miligrama por semente) foram determinados em estufa a $103^{\circ} \mathrm{C}$ por 17 horas (International Seed Testing Association, 1996), com três repetições de 
cinco sementes cada. Os testes de germinação foram conduzidos em câmara de germinação a $25 \pm 1^{\circ} \mathrm{C}$ e $85 \pm 5 \%$ de umidade relativa (UR). Amostras das sementes de cada classe de tamanho foram colocadas em rolo de papel para germinação Germitest, umedecidos previamente com água de torneira (Regras para análise de sementes, 2009), em 8 repetições de 15 sementes cada. Registrou-se o número de raízes e de plântulas produzidas a cada cinco dias, até que não houvesse mais emissão de novas raízes ou epicótilos por 30 dias consecutivos.

As sementes foram divididas em dois subgrupos, um dos quais, denominado sementes germinantes, foi colocado para germinar em bandejas de plástico que continha substrato vermiculita de granulação fina, irrigado diariamente com água. As sementes foram retiradas do substrato à medida que as raízes atingiam $1 \mathrm{~cm}$ de comprimento, e então armazenadas em câmaras a $7^{\circ} \mathrm{C}$, dentro de sacos de polietileno perfurados, até o início dos experimentos, juntamente com as sementes do subgrupo não germinante.

Sementes de cada subgrupo e do grupo controle (sementes inteiras, sem lesões) foram submetidas a dois tipos de incisão (completa ou parcial) com bisturi, que passava pelo centro do hilo. Em sementes germinantes, a incisão foi realizada de modo que um dos lados permaneceu com toda a raiz protrusa. $\mathrm{Na}$ incisão completa, denominada fracionamento, duas frações foram obtidas e colocadas para germinar lado a lado, conforme descrito anteriormente. Em sementes germinantes, a fração que continha a raiz foi denominada fração R, e sua oposta, fração S. Nas não germinantes, essa denominação foi arbitrária. Na incisão parcial, denominada fissura, ela foi realizada até cerca de dois terços do maior diâmetro das sementes, tendo-se mantido as metades ligadas.

Foram selecionadas as sementes fissuradas que apresentavam, ao final dos testes de germinação, apenas uma plântula desenvolvida, sem desenvolvimento visível de novas raízes. Nessas sementes, completouse a incisão até que as metades fossem separadas. A metade que continha a raiz foi descartada, e sua complementar foi colocada para germinar, tendo-se mantido o controle de sua origem e avaliado novamente a produção de raízes e plântulas nas frações isoladas.

Em todos os experimentos utilizou-se o delineamento inteiramente casualizado, em arranjo fatorial $2 \times 2$ (tamanho das sementes $\mathrm{x}$ germinação visível) ou $2 \times 4$ (tamanho das sementes $\mathrm{x}$ tipo de incisão). Os dados foram submetidos à análise de variância, e as médias foram comparadas pelo teste de Tukey, a 5\% de probabilidade, pelo Sisvar 5.3 (Ferreira, 2008).

\section{Resultados e Discussão}

O teor de água das sementes de uvaieira foi compatível com o de sementes maduras (59,4 e 57,8\%, para grandes e pequenas, respectivamente), e o tamanho inicial não influenciou os valores de germinação $(98 \%$ em ambas) e de desenvolvimento de plântulas normais (98\% em ambas), o que mostra a elevada qualidade fisiológica do lote. Contudo, quando as sementes foram submetidas a fracionamentos, a resposta das sementes grandes e pequenas foi diferente, pois as pequenas apresentaram menores valores de produção de raízes e de plântulas do que as grandes (Tabela 1). As sementes fracionadas, de ambos os tamanhos, produziram, em média, sempre mais de uma raiz, o que confirma o potencial de regeneração de raízes (Silva et al., 2003). Nas sementes grandes, observaram-se médias superiores a 1,7 raízes por semente. No entanto, poucas plântulas foram desenvolvidas a partir da formação da segunda raiz, independentemente do tamanho da semente.

A produção de raízes das sementes germinantes foi inferior à das não germinantes (Tabela 1). Uma possível explicação para esse resultado seria que o desenvolvimento de uma raiz inicial, no subgrupo germinante, causou uma eficiência muito baixa para regenerar uma nova raiz, o que reforça a ideia de algum processo de autoinibição nessas sementes, quando se

Tabela 1. Média do número de raízes e plântulas por semente de uvaieira (Eugenia pyriformis), de sementes com tamanhos distintos, sem germinação visível (não germinantes) ou após a protrusão de ao menos $1 \mathrm{~cm}$ de raiz (germinante), submetidas a fracionamento ao meio na região do hilo. Valores representam a soma das duas frações de uma mesma semente ${ }^{(1)}$.

\begin{tabular}{|c|c|c|}
\hline \multirow{2}{*}{$\begin{array}{l}\text { Tamanho } \\
\text { da semente }\end{array}$} & \multicolumn{2}{|c|}{ Condição de germinação } \\
\hline & Germinante & Não germinante \\
\hline & \multicolumn{2}{|c|}{ Raiz } \\
\hline Pequena & $1,30 \mathrm{bB}$ & $1,45 \mathrm{bA}$ \\
\hline \multirow[t]{2}{*}{ Grande } & $1,43 \mathrm{aB}$ & $1,73 \mathrm{aA}$ \\
\hline & \multicolumn{2}{|c|}{ Plântula } \\
\hline Pequena & $0,81 \mathrm{aA}$ & $0,67 \mathrm{bB}$ \\
\hline Grande & $0,89 \mathrm{aA}$ & $0,92 \mathrm{aA}$ \\
\hline
\end{tabular}

(1)Médias seguidas de letras iguais, minúsculas nas colunas e maiúsculas nas linhas, não diferem pelo teste de Tukey, a $5 \%$ de probabilidade. 
inicia a germinação (Silva et al., 2005). Tal fato ficou evidente pela análise das frações individualizadas, uma vez que nas frações que não permaneceram com a raiz, nas sementes germinantes (Tabela 2), a formação de novas raízes foi cerca de $50 \%(0,3$ a 0,6 raízes por fração) dos valores obtidos para as frações não germinantes $(0,7$ a 0,9 raízes por fração). Essa diferença foi mantida quanto ao desenvolvimento de plântulas.

$\mathrm{Na}$ fração oposta à germinante $(\mathrm{S})$, além dos valores finais de regeneração de raízes terem sido inferiores aos das demais frações, também verificou-se atraso no início de emissão de novas raízes (Figura 1), que ocorreu do décimo quinto ao vigésimo quinto dias, enquanto nas demais frações as emissões concentraram-se no quinto dia e finalizaram no décimo quinto dia. $\mathrm{O}$ atraso na germinação das sementes de uma espécie, promovido pela liberação de substâncias inibidoras de outra, tem sido demonstrado em estudos de alelopatia (Hegab et al., 2008; Gatti et al., 2010; Souza et al., 2010; Zhang et al., 2011), o que indica que, em processos de inibição, a redução da percentagem final de germinação nem sempre é evidente. No presente trabalho, contudo, observaramse ambos os efeitos sobre a regeneração de novas raízes (inibição e atraso) em razão do início da germinação das sementes.

Tabela 2. Média do número de raízes e plântulas por semente ou fração de semente de uvaieira (Eugenia pyriformis), de sementes pequenas e grandes, sem germinação visível, ou após a protrusão de ao menos $1 \mathrm{~cm}$ de raiz, submetidas a fracionamento (separação total da semente em duas metades, para gerar as frações R e S) ou fissura (incisão ao meio até 2/3 do diâmetro da semente, sem separação completa) ${ }^{(1)}$.

\begin{tabular}{lccccc}
\hline Tipo de incisão & \multicolumn{2}{c}{ Com germinação visível } & \multicolumn{2}{c}{ Sem germinação visível } \\
\cline { 2 - 3 } \cline { 6 - 6 } & $\begin{array}{c}\text { Semente } \\
\text { pequena }\end{array}$ & $\begin{array}{c}\text { Semente } \\
\text { grande }\end{array}$ & & $\begin{array}{c}\text { Semente } \\
\text { pequena }\end{array}$ & $\begin{array}{c}\text { Semente } \\
\text { grande }\end{array}$ \\
\hline Semente inteira & $1,00 \mathrm{aA}$ & $1,00 \mathrm{aA}$ & $0,99 \mathrm{bA}$ & $0,94 \mathrm{bA}$ \\
Fração R & $1,00 \mathrm{aA}$ & $1,00 \mathrm{aA}$ & & $0,75 \mathrm{cB}$ & $0,88 \mathrm{bcA}$ \\
Fração S & $0,30 \mathrm{bB}$ & $0,43 \mathrm{bA}$ & $0,70 \mathrm{cB}$ & $0,85 \mathrm{cA}$ \\
Semente fissurada & $1,11 \mathrm{aA}$ & $1,08 \mathrm{aA}$ & $1,52 \mathrm{aB}$ & $1,64 \mathrm{aA}$ \\
\hline \multirow{5}{*}{ Semente inteira } & $0,87 \mathrm{aB}$ & $0,95 \mathrm{aA}$ & $0,75 \mathrm{aA}$ & $0,76 \mathrm{bA}$ \\
Fração R & $0,64 \mathrm{cA}$ & $0,64 \mathrm{cA}$ & $0,35 \mathrm{bB}$ & $0,47 \mathrm{cA}$ \\
Fração S & $0,17 \mathrm{~dB}$ & $0,25 \mathrm{dA}$ & $0,32 \mathrm{bB}$ & $0,45 \mathrm{cA}$ \\
Semente fissurada & $0,72 \mathrm{bA}$ & $0,75 \mathrm{bA}$ & $0,82 \mathrm{aB}$ & $0,98 \mathrm{aA}$ \\
\hline
\end{tabular}

${ }^{(1)}$ Médias seguidas de letras iguais, minúsculas nas colunas e maiúsculas nas linhas, não diferem pelo teste de Tukey, a 5\% de probabilidade.
Quando as sementes foram apenas fissuradas, sem separação em metades, as não germinantes apresentaram valores de formação de raízes superiores a 1,0 (Tabela 2). Tal fato poderia representar algum tipo de estímulo à formação de novas raízes, resultante da incisão realizada nas sementes. Isto, porém, não ocorreu quando a incisão foi realizada nas sementes que haviam iniciado a germinação.

Sementes de uvaieira maduras apresentam eixo embrionário visível apenas microscopicamente (Justo et al., 2007). A regeneração de novas raízes tem origem cotiledonar e, segundo Delgado (2010), das regiões vasculares, o que se assemelha a processos de embriogênese somática. Em Medicago truncatula, verificou-se que o sucesso na obtenção de embriões por embriogênese somática depende da desdiferenciação de células, principalmente do mesofilo, que por sua vez depende de um balanço favorável entre
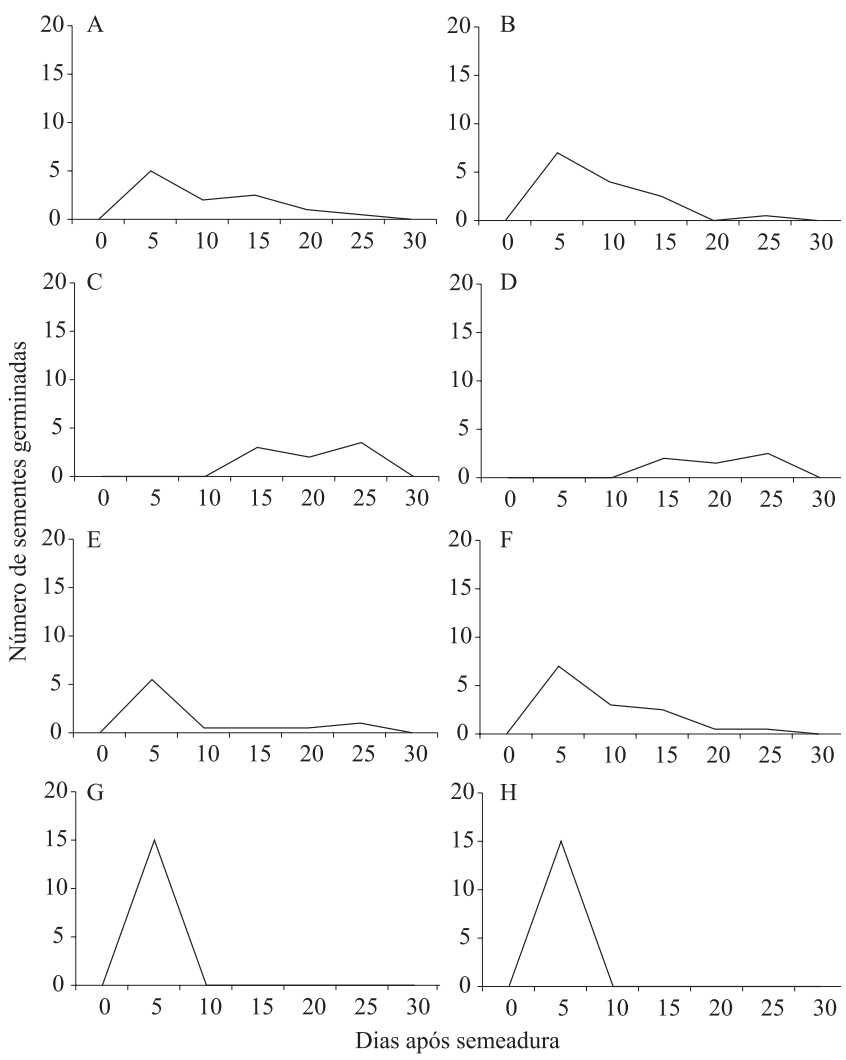

Figura 1. Distribuição temporal de frequência da germinação das frações S (A, B, C e D) e R (E, F, G e H) de sementes de uvaieira (Eugenia pyriformis) grandes (A, C, E e G) e pequenas $(\mathrm{B}, \mathrm{D}, \mathrm{F}$ e $\mathrm{H})$, não germinantes $(\mathrm{A}, \mathrm{B}, \mathrm{E}$ e $\mathrm{F}) \mathrm{e}$ germinantes $(\mathrm{C}, \mathrm{D}, \mathrm{G}$ e $\mathrm{H})$. 
citocininas e auxinas (Wang et al., 2011). Estas últimas mostraram padrões estabelecidos quanto à polaridade de transporte, o que influencia a formação dos novos embriões. Assim, as fissuras nas sementes de uvaieira podem ter alterado o transporte de reguladores, como a auxina, e condicionado maior ou menor eficiência na renegeração de novas raízes e plântulas nessas sementes.

Sementes fissuradas, colocadas para germinar, produziram raízes e plântulas que foram agrupadas em seis categorias (Figura 2). Nas sementes germinantes, a raiz inicial completou o desenvolvimento e formou uma plântula normal em $100 \%$ das sementes. Quando as sementes eram pequenas, em apenas $11 \%$ das fissuradas houve o início de formação de uma nova raiz, que ocorreu na face fissurada oposta à que continha a plântula, ou seja, na categoria IV; nas sementes grandes, esse valor foi maior (18\%). Contudo, prevaleceu para ambos os tamanhos a categoria III, ou seja, sem desenvolvimento de uma
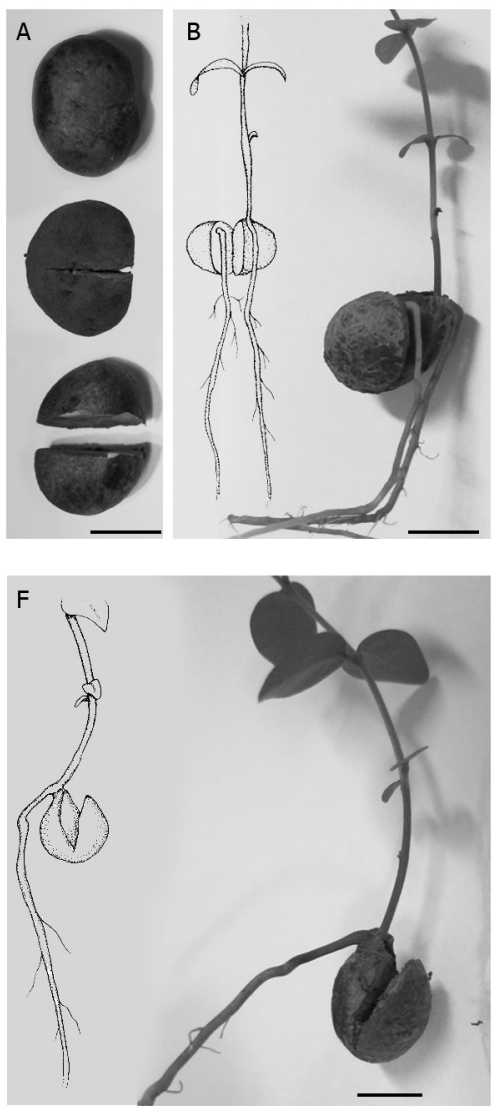
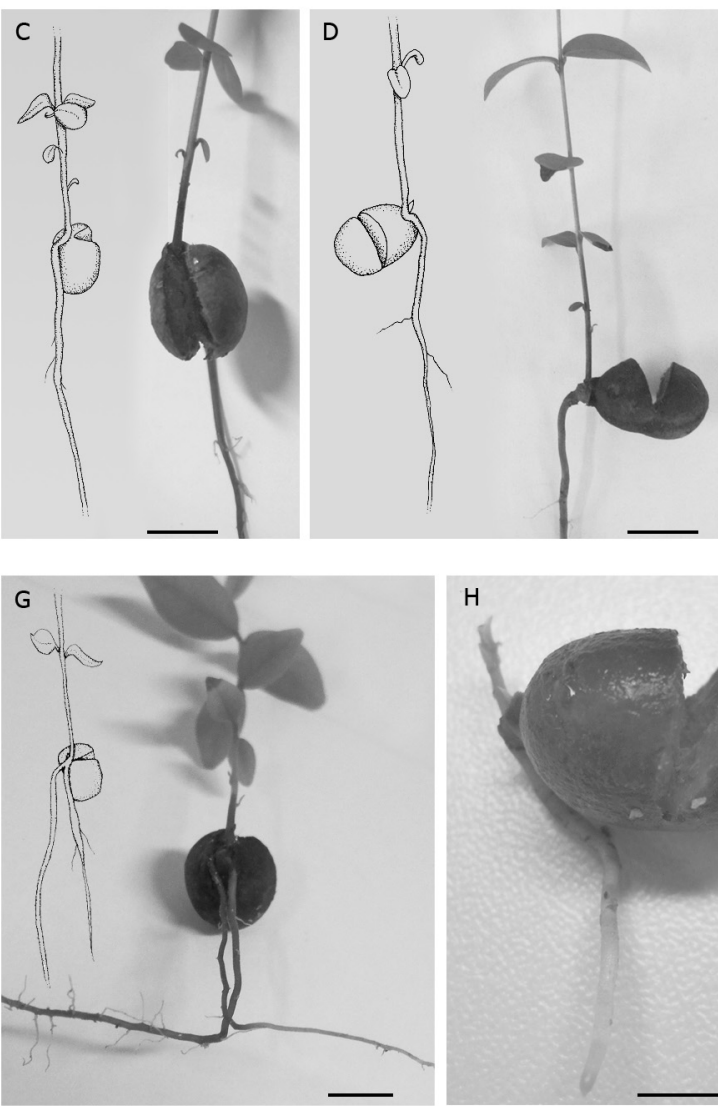
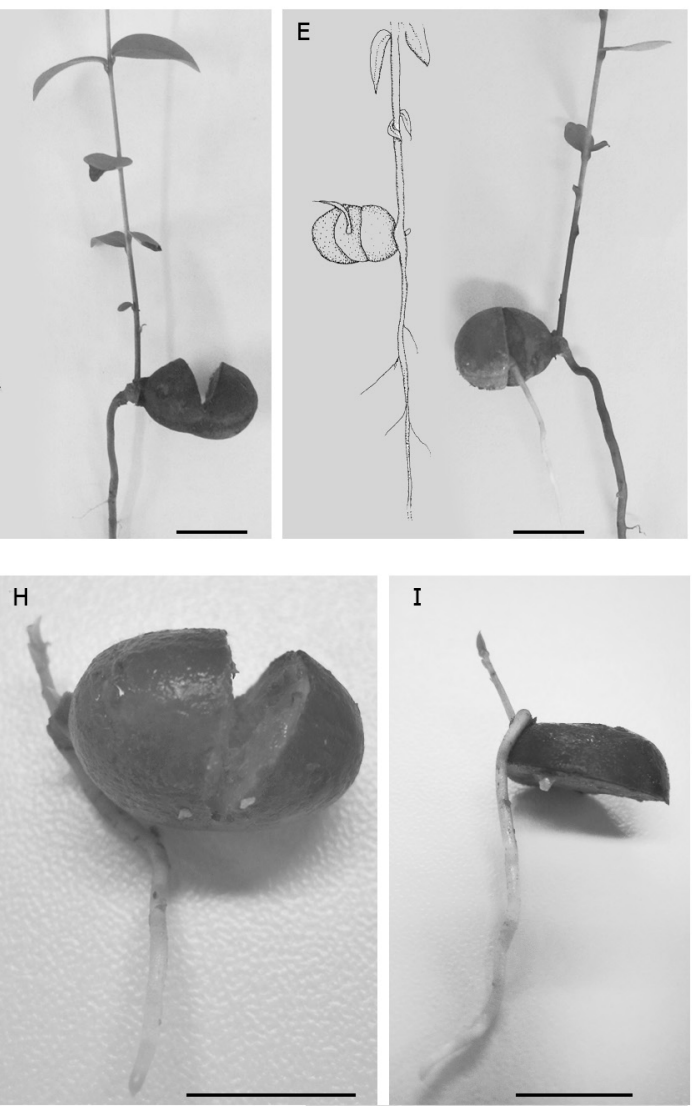

Figura 2. Modelos de incisões feitas em sementes de uvaieira (Eugenia pyriformis) e categorias de germinação. A, de cima para baixo, semente inteira, semente fissurada (incisão no hilo, até $2 / 3$ do diâmetro da semente, sem separação completa) e semente fracionada (incisão completa, no hilo, com separação em duas metades); B a G, categorias de crescimento de raiz e parte aérea: B, categoria I, formação de uma plântula normal em uma das metades da semente que foi separada pela fissura, iniciada na região adjacente à fissura, e formação de outra raiz na outra metade; C, categoria II, formação apenas de uma plântula normal na região diametralmente oposta à fissura, iniciada na região adjacente à fissura; D, categoria III, formação de apenas uma plântula normal em uma das metades, iniciada em região distante da fissura; E, categoria IV, formação de uma plântula normal em uma das metades, iniciada em região distante da fissura e formação de uma raiz na outra metade, iniciada na superfície fissurada; $\mathrm{F}$, categoria $\mathrm{V}$, formação de uma plântula normal em uma das metades, iniciada na região adjacente à fissura; G, categoria VI, formação de uma plântula normal e de uma raiz na região oposta à fissura, ambas iniciadas na região adjacente à fissura; H, semente fissurada com plântula desenvolvida; I, plântula desenvolvida a partir de fração complementar àquela na qual já havia plântula e que foi descartada. Escala: $1,5 \mathrm{~cm}$. Ilustração: Débora Manzano Molizane. 
segunda raiz. Na categoria III estavam 88 e $83 \%$ das sementes, pequenas e grandes, respectivamente. Entretanto, as sementes não germinantes fissuradas, que foram colocadas para germinar, produziram raízes e plântulas principalmente nas categorias I, II e V. Ressalta-se, contudo, que mais da metade desses valores -55 e $57 \%$, para sementes pequenas e grandes, respectivamente - situaram-se na categoria I, ou seja, com formação de uma plântula normal em um dos lados da fissura e uma raiz no outro, o que indica que a fissura promoveu algum bloqueio à possível inibição do desenvolvimento de uma segunda raiz pela protrusão da primeira.

O comportamento das sementes não germinantes fissuradas indica que o processo de inibição pode não ter ocorrido em todo o tecido da semente, uma vez que a fissura foi realizada antes do início da germinação, diferentemente do que ocorreu nas germinantes fissuradas. A mobilização e o transporte de muitos reguladores vegetais foram amplamente estudados em diversos tecidos, inclusive nas sementes, mas concentram-se nos promotores de divisão e crescimento celular (Hirose et al., 2008; Ongaro \& Leyser, 2008; Jeong et al., 2011). Porém, pouca atenção tem sido dada aos inibidores. Processos que tenham a participação do ácido abscísico, por exemplo, reconhecidamente um dos inibidores mais importantes em diversos processos vegetais, necessitam ainda ser elucidados, tais como o transporte dentro e entre tecidos da semente (Weyers \& Paterson, 2001; Kermode, 2005)

Nas sementes não germinantes, $18 \%$ das pequenas e $24 \%$ das grandes tiveram formação de uma plântula normal na região central, em posição oposta à incisão (categoria II, Figura $2 \mathrm{C}$ ), sem formação de uma segunda raiz. Isso pode ser decorrente do fato de que a germinação iniciada na região central, próxima à incisão, permitiu distribuição uniforme de potenciais inibidores por toda a semente.

Após o final dos testes de germinação das sementes fissuradas (Figura $2 \mathrm{H}$ ), as categorias III, para sementes germinantes, e II e V, para as não germinantes, apresentaram os maiores valores de produção de plântulas que não tiveram regeneração de uma segunda raiz. Quando se realizou o fracionamento das sementes fissuradas, as frações opostas às frações com protusão da raíz formaram nova raiz em $33 \%$ das sementes grandes e $28 \%$ das pequenas, se provenientes do subgrupo germinante. Em alguns casos, observou-se até a formação de uma nova parte aérea (Figura 2 I). Quando essas frações eram originárias do subgrupo não germinante, a germinação das frações opostas às germinantes foi de 53 e $50 \%$, nas categorias II e $\mathrm{V}$ das sementes grandes, respectivamente, e de 52 e $60 \%$, nas pequenas. Esses resultados são evidência de que há processos de inibição do desenvolvimento de novas raízes, promovidos pelo desenvolvimento de uma raiz ou plântula na mesma semente. Além disso, a produção de compostos inibidores deve ser contínua, cumulativa e oriunda da região na qual há crescimento da plântula, visto que, em sementes germinantes, nas quais a plântula estava há mais tempo ligada ao cotilédone, a percentagem de germinação foi menor do que nas não germinantes. No entanto, não deve ser descartada a possibilidade de que as sementes germinantes tenham consumido maior quantidade de reservas do que as não germinantes e que a diferença na percentagem final de germinação seja decorrente de diferença na disponibilidade de reservas para a formação de novas raízes. De fato, Silva et al. (2003) demonstraram que o aumento no número de fracionamentos dessas sementes reduz a capacidade de regeneração de plântulas, principalmente em razão da redução na disponibilidade de reservas para cada plântula formada. $\mathrm{O}$ maior desenvolvimento das plântulas de sementes grandes obtido no presente trabalho (Tabela 1) também indica tal interferência.

$\mathrm{O}$ desenvolvimento de uma segunda raiz em uma mesma semente de uvaieira é dependente do bloqueio de substâncias ou de processos de inibição que se iniciam quando a primeira germinação ocorre, o que foi confirmado nas sementes fissuradas. No entanto, a germinação e a dormência de sementes são, provavelmente, resultado de um balanço entre diversos fatores promotores e inibidores, entre os quais figuram GA e ABA (Leubner-Metzger, 2003). Portanto, não se pode eliminar a possibilidade de que as sementes fracionadas estejam sob influência dos dois processos, indução e inibição, com balanço ora favorável ao desenvolvimento de novas raízes e plântulas, ora desfavorável. Assim, nas sementes inteiras, a formação de uma única raiz pode ser decorrente da falta de estímulo à regeneração ou de um balanço favorável à inibição. Contudo, nas sementes fracionadas, ficou evidenciado que o estímulo à regeneração ocorre e que, quando a germinação se inicia, também se iniciam processos de inibição da regeneração de novas raízes e plântulas. 


\section{Conclusões}

1. Sementes de uvaieira apresentam potencial para regeneração de raízes e plântulas e podem produzir mais de uma muda a partir de uma mesma semente.

2. A germinação de sementes de uvaieira inicia processos de inibição da regeneração de novas raízes e plântulas na semente.

3. A incisão dos cotilédones pode bloquear a ação desses processos inibidores.

\section{Agradecimentos}

Ao Conselho Nacional de Desenvolvimento Científico e Tecnológico, por concessão de bolsas e apoio financeiro ao projeto; à Fundação de Amparo à Pesquisa do Estado de São Paulo, por apoio financeiro ao projeto; a Edmir Vicente Lamarca, pelo auxílio na obtenção do material vegetal; e a Debora Manzano Molizane, pela confecção das ilustrações.

\section{Referências}

ANJOS, A.M.G. dos; FERRAZ, I.D.K. Morfologia, germinação e teor de água das sementes de araçá-boi (Eugenia stipitata ssp. sororia). Acta Amazonica, v.29, p.337-348, 1999.

DELGADO, L.F. Fracionamento, maturação e origem da capacidade regenerativa de sementes de algumas espécies brasileiras de Eugenia (Myrtaceae). 2010. 92p. Tese (Doutorado) - Instituto de Botânica, São Paulo.

DELGADO, L.F.; BARBEDO, C.J. Tolerância à dessecação de sementes de espécies de Eugenia. Pesquisa Agropecuária Brasileira, v.42, p.265-272, 2007.

DELGADO, L.P.; MELLO, J.I.O.; BARBEDO, C.J. Potential for regeneration and propagation from cut seeds of Eugenia (Myrtaceae) tropical tree species. Seed Science and Technology, v.38, p.624-634, 2010.

DEO, P.C.; TYAGI, A.P.; TAYLOR, M.; HARDING, R.; BECKER, D. Factors affecting somatic embryogenesis and transformation in modern plant breeding. The South Pacific Journal of Natural and Applied Sciences, v.28, p.27-40, 2010.

FERREIRA, D.F. SISVAR: um programa para análises e ensino de estatística. Revista Symposium, v.6, p.36-41, 2008.

GATTI, A.B.; FERREIRA, A.G.; ARDUIN, M.; PEREZ, S.C.G. de A. Allelopathic effects of aqueous extracts of Aristolochia esperanzae O.Kuntze on development of Sesamum indicum L. seedlings. Acta Botanica Brasilica, v.24, p.454-461, 2010.

GURGEL, J.T.A.; SOUBIHE SOBRINHO, J. Poliembrionia em mirtáceas frutíferas. Bragantia, v.11, p.141-163, 1951.

HEGAB, M.M.; KHODARY, S.E.A.; HAMMOUDA, O.; GHAREIB, H.R. Autotoxicity of chard and its allelopathic potentiality on germination and some metabolic activities associated with growth of wheat seedlings. African Journal of Biotechnology, v.7, p.884-892, 2008.

HIROSE, N.; TAKEI, K.; KUROHA, T.; KAMADA-NOBUSADA, T.; HAYASHI, H.; SAKAKIBARA, H. Regulation of cytokinin biosynthesis, compartmentalization and translocation. Journal of Experimental Botany, v.59, p.75-83, 2008.

INTERNATIONAL SEED TESTING ASSOCIATION. International rules for testing seeds. Seed Science and Technology, v.16, p.113-115, 1996.

JEONG, S.; BAYER, M.; LUKOWITZ, W. Taking the very first steps: from polarity to axial domains in the early Arabidopsis embryo. Journal of Experimental Botany, v.62, p.1687-1697, 2011.

JUSTO, C.F.; ALVARENGA, A.A. de; ALVES, E.; GUIMARÃES, R.M.; STRASSBURG, R.C. Efeito da secagem, do armazenamento e da germinação sobre a micromorfologia de sementes de Eugenia pyriformis Camb. Acta Botanica Brasilica, v.21, p.539-551, 2007.

KANWAR, K.; JOSEPH, J.; DEEPIKA, R. Comparison of in vitro regeneration pathways in Punica granatum L. Plant Cell, Tissue and Organ Culture, v.100, p.199-207, 2010.

KARAMI, O.; SAIDI, A. The molecular basis for stress-induced acquisition of somatic embryogenesis. Molecular Biology Reports, v.37, p.2493-2507, 2010.

KERMODE, A.R. Role of abscisic acid in seed dormancy. Journal of Plant Growth Regulation, v.24, p.319-344, 2005.

LANDRUM, L.R.; KAWASAKI, M.L. The genera of Myrtaceae in Brazil: an illustrated synoptic treatment and identification keys. Brittonia, v.49, p.508-536, 1997.

LEUBNER-METZGER, G. Hormonal and molecular events during seed formancy release and germination. In: NICOLÁS, G.; BRADFORD, K.J.; CÔME, D.; PRITCHARD, H.W. The biology of seeds: recent research advances. Wallingford: CABI Publishing, 2003. p.101-112.

OLIVEIRA, E.N.A. de; SANTOS, D. da C.; SOUSA, F.C. de; MARTINS, J.N.; OLIVEIRA, S.P.A. de. Obtenção de ubaia desidratada pelo processo de liofilização. Revista Brasileira de Tecnologia Industrial, v.4, p.235-242, 2010.

ONGARO, V.; LEYSER, O. Hormonal control of shoot branching. Journal of Experimental Botany, v.59, p.67-74, 2008.

PEPATO, M.T.; FOLGADO, V.B.B.; KETTELHUT, I.C.; BRUNETTI, I.L. Lack of antidiabetic effect of a Eugenia jambolana leaf decoction on rat streptozotocin diabetes. Brazilian Journal of Medical and Biological Research, v.34, p.389-395, 2001.

PEREIRA, C.E.; VON PINHO, E.V.R.; OLIVEIRA, D.F.; KIKUTI, A.L.P. Determinação de inibidores da germinação no espermoderma de sementes de café (Coffea arabica L.). Revista Brasileira de Sementes, v.24, p.306-311, 2002.

REGRAS para análise de sementes. Brasília: Ministério da Agricultura, Pecuária e Abastecimento, 2009. 399p.

RIZZINI, C.T. Efeito tegumentar na germinação de Eugenia dysenterica DC. (Myrtaceae). Revista Brasileira de Biologia, v.30, p.381-402, 1970. 
SALOMÃO, A.N.; ALLEM, A.C. Polyembryony in angiospermous trees of the Brazilian Cerrado and Caatinga vegetation. Acta Botanica Brasilica, v.15, p.369-378, 2001.

SCALON, S. de P.Q.; DELL'OLIO, P.; FORNASIERI, J.L. Temperatura e embalagens na conservação pós-colheita de Eugenia uvalha Cambess. - Mirtaceae. Ciência Rural, v.34, p.1965-1968, 2004a.

SCALON, S. de P.Q.; SCALON FILHO, H.; RIGONI, M.R. Armazenamento e germinação de sementes de uvaia Eugenia uvalha Cambess. Ciência e Agrotecnologia, v.28, p.1228-1234, 2004 b.

SILVA, C.V. e; BILIA, D.A.C.; BARBEDO, C.J. Fracionamento e germinação de sementes de Eugenia. Revista Brasileira de Sementes, v.27, p.86-92, 2005.

SILVA, C.V. e; BILIA, D.A.C.; MALUF, A.M.; BARBEDO, C.J. Fracionamento e germinação de sementes de uvaia (Eugenia pyriformis Cambess. - Myrtaceae). Revista Brasileira de Botânica, v.26, p.213-221, 2003.

SOUZA, F.M.; GANDOLFI, S.; PEREZ, S.C.J.G. de A.; RODRIGUES, R.R. Allelopathic potential of bark and leaves of
Esenbeckia leiocarpa Engl. (Rutaceae). Acta Botanica Brasilica, v.24, p.169-174, 2010.

STIEVEN, A.C.; MOREIRA, J.J.S.; SILVA, C.F. Óleos essenciais de uvaia (Eugenia pyriformis Cambess.): avaliação das atividades microbiana e antioxidante. Eclética Química, v.34, p.7-13, 2009.

SWAMY, M.K.; SUDIPTA, K.M.; BALASUBRAMANYA, S.; ANURADHA, M. Effect of different carbon sources on in vitro morphogenetic response of patchouli (Pogostemon cablin Benth.). Journal of Phytology, v.2, p.11-17, 2010.

WANG, X.D.; NOLAN, K.E.; IRWANTO, R.R.; SHEAHAN, M.B.; ROSE, R.J. Ontogeny of embryogenic callus in Medicago truncatula: the fate of the pluripotent and totipotent stem cells. Annals of Botany, v.107, p.599-609, 2011.

WEYERS, J.D.B.; PATERSON, N.W. Plant hormones and the control of physiological processes. New Phytologist, v.152, p.375-407, 2001.

ZHANG, S.; LIU, J.; BAO, X.; NIU, K. Seed-to-seed potential allelopathic effects between Ligularia virgaurea and native grass species of Tibetan alpine grasslands. Ecological Research, v.26, p.47-52, 2011.

Recebido em 25 de março de 2011 e aprovado em 10 de agosto de 2011 